\title{
Factors Affecting Organizations' Logistic Outsourcing In The Supply Chain Management In Kenya: A Case Of Kenya Seed Company Limited
}

\author{
Joyclare Khakasa Wabuge, Dr. Anthony Osoro \\ (PhD) JKUAT, Kenya \\ DOI: 10.29322/IJSRP.10.02.2020.p9836 \\ http://dx.doi.org/10.29322/IJSRP.10.02.2020.p9836
}

\begin{abstract}
This study explored on the factors affecting organization's logistics-outsourcing in the supply chain management in Kenya Seed Company Limited. The specific areas were; to evaluate the effect of information systems, supplier relationships, order processing and inventory management in systems in the supply chain in Kenya Seed Company Limited.
\end{abstract}

Index Terms- Information systems, supplier relationship, order processing and inventory management.

\section{INTRODUCTION}

Scholars like Achuora, Arasa and Ochiri (2014) have defined logistics as part of a supply chain which involves with the forward and reverse flow of goods \& services, cash and information. Many companies following the trend of increased outsourcing are rationalizing their existing outsourced logistics operations because companies can minimize their cost and also maximize the value of the company. There is a growing need to be quick to respond to customer and market demand; logistics activities involve a large commitment of capital. The logistics function can be the key facilitator in cross functional effort towards supply chain integration. In Kenya, many organizations and institutions have adopted outsourcing of services and goods from third parties due to the benefits resulting from this such as lower cost to the organization, satisfied customers and most important relieving the management to deal with more strategic issues by conceding the non-core functions to specialized firms (Agaba \& Shipman, 2014). A report by the Bureau of Transport Economics states that the performance of the logistics system had a major impact on the economy: "It affected the cost structures and revenues of Australian producers, their effectiveness in areas such as delivery times and product quality and the responsiveness of producers to consumer requirements (Bali, Kose \& Gumus, 2013). Also, Agaba and Shipman (2014) stated that due to the trend of nationalization and globalization in recent decades, the importance of logistics management had been growing in various areas. Efficient flow of goods and information were only possible if there was a well-developed transport and communication infrastructure. Consequently, incompetent transport and communication formed a major obstacle in achieving efficiently organized flows of goods and services. If farmers and manufacturers were to take advantage of reforms in agriculture and other productive systems, dependable transport and communication systems were vital. Such systems were of major importance for the facilitation of internal and external trade. Investments in infrastructure would improve distribution logistics, increase productivity and lower production costs (WB, 2010). Keeping track of orders, shipping, inventory and returns, along with various other supply chain functions can be extremely time-consuming and expensive for many companies. Outsourcing these processes can be the ideal solution. Logistics outsourcing helps the firm expand internationally and operate on a much larger scale. You can do business wherever the opportunity presents itself by setting up delivery operations in another country within a relatively short time frame (Bansal, ving \& Taylor, 2014).

\subsection{Statement of the Problem}

Despite the fact that firms are able to internally perform most production and service provision activities, many still choose to outsource these activities to 3PL service providers (Bailey, 2016). Outsourcing logistics saves a wealth of time and money that would otherwise be spent sourcing internally. Firms that chose to use 3PLs providers are able to eliminate the need to invest in warehouse space, technology, transportation and staff to execute the logistics internally. Using 3PL providers also keeps the organization up to date as far as the ongoing trends in the industry is concerned. Various studies have been conducted to establish a link between outsourcing logistics and firm performance. Gikonyo (2016) conducted a study to explore the extent of outsourcing of the logistics function within the manufacturing industry. The research was carried out on the effect of order warehousing, packaging and transport logistics outsourcing on the performance of the logistics in Kenya. On the other hand, also Makabira and Waiganjo (2014). conducted a study on the effect of outsourcing on the operational performance of shipping industry in Kenya. The objective of the study was to determine outsourcing effect on operational performance of shipping industries in Kenya. According Masiko (2013) did a study on logistics outsourcing but was comparing logistics outsourcing practices and performance of large manufacturing firms in Nairobi. He established that logistics outsourcing practices being adopted by the large manufacturing firms resulted to increased productivity, organizational effectiveness, increased profits, continuous improvement and improved quality. Therefore this study endeavored to bridge the existing gap by creating new knowledge out of this study by identifying the factors affecting organizations' Information systems, supplier relationship, order processing and inventory 
management the link the same to logistic-outsourcing in a supply chain management .

\section{2.1 INFORMATION SYSTEM}

The role of the MIS in an organization can be compared to the role of heart in the body. The information is the blood and MIS is the heart. In the body the heart plays the role of supplying pure blood to all the elements of the body including the brain. The heart works faster and supplies more blood when needed. It regulates and controls the incoming impure blood, processes it and sends it to the destination in the quantity needed. It fulfills the needs of blood supply to human body in normal course and also in crisis. MIS plays exactly the same role in the organization (Bailey, 2016). The system ensures that an appropriate data is collected from the various sources, processed, and sent further to all the needy destinations. The system is expected to fulfill the information needs of an individual, a group of individuals, the management functionaries, the managers and the top management. MIS satisfies the diverse needs through a variety of systems such as Query Systems, Analysis Systems, Modeling Systems and Decision Support Systems, MIS helps in Strategic Planning, Management Control, Operational Control and Transaction Processing ( Makabira \& Waiganjo, 2014).

Information systems (IS) involve a variety of in-formation technologies such as computers, soft-ware, databases, communication systems, the Inter-net, mobile devices and much more, to perform specific tasks, interact with and inform various actors in different organizational or social contexts. Of general interest to the field of IS are therefore all aspects of the development, deployment, implementation, use and impact of IS in organizations and society (Nyongesa \& Osoro, 2019).The effectiveness and accuracy of distribution systems depend on the transfer of information (Nelson, Moody \& Stegner, 2014). An information system is a mainframe system linking a number of computers together. Information system links up the logistical activities. It integrates a number of information sources, including the order information, purchasing information, production information schedule, the packaging information schedule, the transport and warehousing information, the distribution information, the payment information and the delivery information. It serves to enable logisticians retrieve date as and when it is required, process data through the system and analyze data (Bansal, Irving \& Taylor, 2014). According to Nasra (2014), logistical information has two major components; planning and coordination and operations. Planning and coordination include the activities necessary to schedule procurement, production and logistics resource allocation throughout the enterprise. Nowadays competitive overall business environment requires effective use of firm resources which may be achieved through use of information technology resources for logistics activities (Barsemoi Mwangagi \& Asienyo, 2014). According to Barth, Beave and Landsman (2013), the flow of accurate and real time information in logistics is considered very important to the flow of materials. IT helps in sharing information on transfer or exchange of information indicating the level and position of inventory, sales data and information on the forecasting information, information about the status of orders, production schedules and delivery capacity, and firm performance measures (Wardaya, et al, 2013). Prior research has proved that better information usage can improve the performance of many logistics tasks including distribution of network design, demand forecasting, transport management, inventory management and the processing of orders which is of primary importance to firm performance Bowersox et al., 2012). Effective and efficient information sharing improves the visibility of logistics activities (Barth et al., 2013).

\subsection{Supplier Relationships}

In the beginning, relationship marketing was seen as an attempt to "involve and integrate customers, suppliers and other infrastructural partners into a firm's developmental and marketing activities". In this regard, Bailey (2016), provided one of the most universally recognized definitions of relationship marketing, namely its focus on all marketing activities conducted to create, develop, and manage successful relationships between marketing partners (e.g. suppliers and buyers). Another very good definition of relationship marketing is that of Gikonyo,(2016). who view relationship marketing as a philosophy for re-orientating buyers and suppliers through a business strategy. This brings them together in collaborative and cooperative ways, ensuring synergetic, trusting and mutually beneficial relationships.

Later, Bailey (2016)emphasized the long-term and valueadding nature of such relational exchanges, while more recently the key emphasis has shifted to the mutuality of such long-term and value-adding relationships Kothari (2014) and the question of relative returns of such relationships Further, building on the socalled service-dominant logic of marketing or the broader service logic, Bailey (2016) also emphasized the role of services as a "mediating factor" in the process of mutual buyer-supplier value creations, where true value is created not only through exchanges, but from active engagement and integration of partners in each other's processes. This is more consistent with relationship marketing as a synonym for a network perspective on buyersupplier relationships

Supplier relationship is the systematic, enterprise-wide assessment of suppliers' assets and capabilities with respect to overall business strategy, determination of what activities to engage in with different suppliers, and planning and execution of all interactions with suppliers, in a coordinated fashion across the relationship life cycle, to maximize the value realized through those interactions. According to Nyaga et al., (2010), in joint relationships between customers and traders, joint relationship efforts play an important role and the influence of such effort is directly related to trust and not to commitment. In addition to this, the impact of joint relationship efforts is greater for suppliers than for buyers. SRM necessitates a consistency of approach and a defined set of behaviors that foster trust over time. Effective SRM requires not only institutionalizing new ways of collaborating with key suppliers, but also actively dismantling existing policies and practices that can impede collaboration and limit the potential value that can be derived from key supplier relationships (Basheka, 2016).-At the same time, SRM should entail reciprocal changes in processes and policies at suppliers. Thus, joint efforts may not be seen as 'strategic' and do not directly influence a firm's long-term commitment to a particular relationship (Bartik, 2016). The length of time that two firms have been involved in a buyersupplier relationship is dependent on the effective control mechanism that manages these inter-organizational relationships 
and consequent performance increases or decreases achieved as a result of a firm's inclusion as a party to it (Basheka \& Tumutegyereize, 2016).

\subsection{Order Processing}

Order processing is the term used to ascertain the collective tasks associated with achieving an order for goods or services placed by a customer (Benton, 2014). The order processing system is the communications network which provides information necessary for the management of the interfaces between logistics and the other functional areas of the firm as well as within logistics (Basheka, 2016). The order fulfillment process is often viewed as transactional and part of the logistics function within a firm. However, it is important that managers recognize its strategic components, its cross-functional needs, and its role within the management of the supply chain. At the strategic level, the order fulfillment process involves understanding the internal and external requirements and assuring that the system has adequate capabilities. This includes understanding the business strategy and the customer service requirements, and designing a supply chain network to meet customers' needs efficiently. Another important component of the process is to have a responsive system in place for when demand exceeds supply and some orders cannot be filled. A The order processing procedure begun with the acceptance of the order from the customer, and it's not considered complete until the customer receives the products and determined that orders have been delivered accurately and completely (Benton, 2014). The order processing procedure begun with the acceptance of the order from the customer and it's not considered complete until the customer receives the products and determined that orders have been delivered accurately and completely. It has three principal functions for a firm it created a flow of information that preceded the goods, accompanied them and followed them (goods) (Bergman \& Lundberg, 2013).

There is no timely information on changes in demand and one has to deal with a long lead time between placing an order and receiving the products. Because of this long lead time, the reaction time is too long; in the game it takes over 4 weeks to respond to sudden changes in demand. This also leads to 'misperceptions of feedback', i.e. subjects tend to disregard the inventory in the pipeline they ordered earlier and keep on ordering more. Next to these aspects Chalotra (2013) found a number of additional causes in real-life supply chains: ?? order batching due to economies of scale in ordering (quantity discounts) and transportation (full truck loads) and the use of periodic planning systems; price fluctuations driven by promotions; and rationing and shortage gaming; i.e. the incentive to increase orders during shortages, place orders with multiple firms, and cancel orders once inventory arrives. Several redesign strategies are proposed to reduce demand amplification and improve supply chain performance: Eliminate all time delays in goods and information flows from the supply chain; Exchange information concerning true market demand with parties upstream the supply chain; ?? Remove one or more intermediate echelons in the supply chain by business take-over; Improve the decision rules at each stage of the supply chain: modify the order quantity procedures or their parameters. Fatiha (2014) quantified the impact of these improvement options and showed that the performance could be drastically improved if the configuration and operational management of the supply chain, the essence of SCM, is changed

For most manufacturers, the supply chain looks less like a pipeline or chain than an uprooted tree, where the branches and roots are the extensive network of customers and suppliers. The question is how many of and how intensive these branches and roots need to be managed. Management will need to choose the level of partnership appropriate for each particular supply chain member knowing that firm capabilities in time and effort are limited (Evans, 2015). With some suppliers partnerships are required since the raw materials they deliver are crucial; others are less important and only have to be monitored. The key is to sort out which members are critical to the success of the company and the supply chain in line with the supply chain objectives - and, thus, should be allocated managerial attention and resources. What processes should be linked with each key member? Successful SCM requires a change from managing individual order business processes within one organization to integrating activities over organizations into key supply chain processes. Fatiha (2014) he identified eight key business processes that could be integrated with the key members in the supply chain. It is usually not necessary to integrate all processes; e.g. if the order winner is responsiveness focus should be on order fulfilment, whereas if the order winner is innovation focus should be on joint product development.

And the longer the delivery lead time can be, the more efficiently the supply chain can be managed. The general trend for the position of the DP is to shift upstream the supply chain, i.e. the planning and execution of activities at industrial manufacturers and primary producers are more and more based on consumer order demand information (Evans, 2015). A good example is the fabrication of cars; nowadays cars are assembled only after the customer order has been received requiring very flexible manufacturing systems. Increasing responsiveness by relocating the decoupling point in the supply chain 15 years ago, the computer industry was characterized by delivery lead times up to multiple weeks - mainly because the production lead time was very long. Since then, customer requirements have changed resulting in a request for short delivery lead times and a large product portfolio. Producers have reacted to this by shifting the decoupling point upstream in the supply chain (Ganesh Kumar \& Nambirajan, 2013).

In order to keep the business profitable order processing should focus on; internet technology to establish high-speed information exchange and have direct customer order information i.e. thereby eliminating the dealer network, product standardization and modularization when using generic or modular inventory the final commitment to a specific customer order is postponed, close partnerships with suppliers that deliver the requested modules at the requested time and place, increased production /assembly flexibility, and fast transportation structures. Nowadays, computers are assembled to order and the requested configuration can be delivered within a few days. Benefits of Supply Chain Management; The profitability of the supply chain could be improved drastically via better order delivery performance such as improved responsiveness and reliability of deliveries, fewer stock outs, higher product quality, more receiverfriendly loads and increased information availability such as better 
demand insight, more predictable order cycles, accurate and realtime at the operational level and a reduction of time-to- market at the tactical and strategic level (Evans, 2015). The potential for improvement when applying SCM-concepts is based on the reduction of inventory-carrying such as reduced overstocks, faster inventory turns and transportation costs (pooling of transport), the reduction of indirect and direct labour costs and the increase of sales and sales margins. Many companies are re-engineering and rationalizing their supply chain network to obtain these benefits.

\subsection{Inventory Management}

The importance of proper inventory management is evident when one considers that inventories have lead to the demise of many a business. The downfall of some companies results from the fact that they are simply unaware of, or do not consider, the cost of inventory. Inventory is generally considered as a safety factor, the lubrication between different parts in the supply chain that enhances the smooth functioning of the total chain. In recent times, however, inventory has come to be considered more and more as a liability (Arthur, 2016). Yet the basic function of inventory, namely saving in other areas and providing 'insurance', cannot be denied. The challenge is to balance the need for inventory against the cost of carrying inventory. There are various reasons why businesses on different levels in the supply chain hold inventory. The functions of inventories can be classified into the following broad categories: decoupling, balancing supply and demand, buffering against uncertainties in supply and demand geographical specialization and preventing the cost of a stock out (Bailey, 2016).

Inventory management is the branch of business management that covers the planning and control of the inventory. An inventory management system is the combination of hardware and software, processes and procedures that oversee the monitoring and maintenance of stocked products raw materials and supplies, or finished products ready to be sent to vendors or end consumers (Nasra, 2014). Inventory management is one of the important key activities of business logistics. Because of its role in business organizations, inventory is one of the most important instruments of logistics planning and control. While inventory on work in process is linked to the production process, physical inventory on stock or in buffer storage is unnecessary from the standpoint of added value and is considered as waste of time and money (tied-up capital). Bergman and Lundberg (2013) are of the opinion that inventory typically represents the second largest component of logistics cost next to transportation. The risks associated with holding inventory increase as products move down the supply chain closer to the customer because the potential of having the product in the wrong place or form increases and costs have been incurred to move the product down the channel. In addition to the risk of lost sales due to stock outs because adequate inventory is not available, other risks include obsolescence, pilferage and damage. According to Nasong'o and Osoro (2019), inventory is a significant asset in most organizations. Its effective management, therefore, is a key task within the auspices of operations. But controlling inventory is far from easy. It involves a complex set of decisions due to the many forms inventory takes and functions it provide. In addition, inventories are the result of functional policies within an organization as well as the short and long term decisions in purchasing, operations and sales.
The optimal management of inventories is a primary objective for all the firms manufacturing make to stock finished goods. As a matter of fact, inventories have important implications for both the financial and the economic performance of the company; therefore it is widely acknowledged that an optimal inventory management policy allows companies to achieve higher profitability levels. In general terms, inventory management policies should be aimed at lowering the holding costs through higher inventory rotation, but without triggering substantial stock outs and backorders, caused by demand peaks and / or lead time delays (Nelson, Moody \& Stegner, 2014). As all organizations are concerned with inventory management, a particular accent has to be put to it. A well-balanced inventory management implies the coordination of strategic functions for example production, finance and marketing of the organization in order to achieve its objectives. The achievement of any organization's objectives is linked to the relationships of functional goals. That's the reason why strategic policies related to inventory management have to be arrested or conceived in order to achieve the organizational goals. Because, failure to that, an organization will grind to a halt. Inventory management uses a variety of data to keep track of the goods as they move through the process including lot numbers, serial numbers, cost of goods, quantity of goods and the dates when they move through the process. Some inventory management software systems are designed for large enterprise and they may be heavily customized for the particular requirements of those organizations (Newman, 2016).

\subsection{Supply Chain Management}

Supply-chain management is a cross-functional approach that includes managing the movement of raw materials into an organization, certain aspects of the internal processing of materials into finished goods and the movement of finished goods out of the organization and toward the end consumer (Ng'ang'a, 2014). As organizations strive to focus on core competencies and become more flexible, they reduce their ownership of raw materials sources and distribution channels. These functions are increasingly being outsourced to other firms that can perform the activities better or more cost effectively (Newman, 2016). The effect is to increase the number of organizations involved in satisfying customer demand, while reducing managerial control of daily logistics operations. Less control and more supply-chain partners lead to the creation of the concept of supply-chain management. Supply chain management produces benefits such as new efficiencies, higher profits, lower costs and increased collaboration (Ng'ang'a, 2014).

SCM enables companies to better manage demand, carry the right amount of inventory, deal with disruptions, keep costs to a minimum and meet customer demand in the most effective way possible (Nagati \& Rebolledo, 2013). These SCM benefits are achieved through the appropriate strategies and software to help manage the growing complexity of today's supply chains. The purpose of supply-chain management is to improve trust and collaboration among supply chain partners thus improving inventory visibility and the velocity of inventory movement. The most basic version of a supply chain includes a company, its suppliers and the customers of that company (Mutava, 2014). The chain could look like this: raw material producer, manufacturer, distributor, retailer and retail customer. A more complex, supply 
chain would likely include a number of suppliers and suppliers' suppliers, a number of customers and customers' customers or final customers and all the organizations that offer the services required to effectively get products to customers, including thirdparty logistics providers, financial organizations, supply chain software vendors and marketing research providers. These entities also use services from other providers (Mwikali \& Kavale, 2013).

\section{Research Design}

A research design is a detailed plan of how a research study is to be completed; operating variables measurement, sample selection, collection of data and analyzing the results of the study and testing the hypotheses (Creswell, 2013). Descriptive research allows a researcher to describe a certain phenomenon the way it is without manipulating the variables. Cross-sectional analysis has the advantage of avoiding various complicated aspects of the use of data drawn from various points in time, such as serial correlation of residuals. It also has the advantage that the data analysis itself does not need an assumption that the nature of the relationships between variables is stable over time, though this comes at the cost of requiring caution if the results for one time period are to be assumed valid at some different point in time (Kothari, 2011). Cross-section research design was used in this study because it allows researchers to compare many different variables at the same time. Mostly, the design is the logical sequence that connects the empirical data, research questions and conclusions (Creswell, 2013).

\section{III. $\quad 3.1$ INFERENTIAL STATISTICS}

The regression results for the variables, both the dependent variable (Supply Chain Management) and the specific variables (Information Systems, Supplier Relationship, Order Processing and Inventory Management) were analysed and the results reported as presented in the respective tables below. The proposed research hypotheses were the basis of the analysis and the regression output results thereof.

\subsection{Regression Results}

The independent variables in the model were used to explore the indicators of Supply Chain Management. In identifying the variance to which the independent variables affected the dependent variable in the model, the co-efficient of correlation ( $\mathrm{R}$ squared) was used. A goodness fit model was used. Research analysis was then used to make predictions about the collected data.A better and reliable model is depicted by a large value of $\mathrm{R}$ squared.

Table 1.2; Model of Goodness Fit

\begin{tabular}{lllll} 
Model & R & R Square & Adjusted R Square & $\begin{array}{l}\text { Std. Error of the } \\
\text { Estimate }\end{array}$ \\
\hline 1 & $.643^{\mathrm{a}}$ & .589 & .798 & .3563 \\
\hline
\end{tabular}

a. Predictors: (Constant), Information Systems, Supplier Relationship, Order Processing and Inventory Management

The overall contribution of the four independent variables; Information Systems, Supplier Relationship, Order Processing and Inventory Management gave a results of $64.9 \%\left(\mathrm{R}^{2}=0.649\right)$ towards the efficiency on Supply Chain Management improvement after its implementation in the Kenya seed company, and the remaining variance of $35.1 \%$ represents other variables/predictors not used in this study, which can also have effect on the dependent variable. This is in line with the findings of Musau (2015).

\section{Analysis of Variance}

The regression equation was used to test the relationship between independent variables and the dependent variable. Analysis of variance statistics was conducted to determine the differences in the means of the dependent and independent variables to show whether a relationship exists between the two. At $95 \%$ confidence level and when the P-value is @ 0.05 implies that implementation of on Supply Chain Management have a significant relationship with Information Systems, Supplier Relationship, Order Processing and Inventory Management which is significant at $5 \%$ level of significance. Research analysis was then used to make predictions about the collected data.

Table 1. 4 ANOVA

ANOVA $^{\mathrm{a}}$

\begin{tabular}{|c|c|c|c|c|c|}
\hline Model & $\begin{array}{l}\text { Sum of } \\
\text { Squares }\end{array}$ & DF & Mean Square & $\mathbf{F}$ & Sig. \\
\hline
\end{tabular}




\begin{tabular}{lccccc}
\hline Regression & 3.708 & 1 & 100.777 & 12.2896 & $.0001^{\mathrm{b}}$ \\
1 Residual & 6.670 & 83 & 4.585 & & \\
Total & $\mathbf{1 0 . 3 7 8}$ & $\mathbf{8 4}$ & & & \\
\hline
\end{tabular}

a. Dependent Variable: Supply Chain Management

b. Predictors: (Constant), Information Systems, Supplier Relationship, Order Processing and Inventory Management

The F-test as provided by the ANOVA table above is significant relationship to the explained/dependent variable; Supply Chain Management in Kenya Seed Company Limited, and therefore the model has predictive power $\mathrm{F}=12.2896$, $\mathrm{p}<0.001$.

\subsubsection{Multiple Linear Regression Analysis}

The analysed data was as presented in table 4.14 below, where Information Systems explained $11.7 \%$, Supplier Relationship 21.7\%, Order Processing $33.8 \%$ and Inventory Management $17.7 \%$ of the Supply Chain Management at the Kenya Seed Company Limited.

Table 1.3 Regression coefficients Results

\begin{tabular}{|c|c|c|c|c|c|c|}
\hline \multicolumn{7}{|c|}{ Coefficients $^{\mathrm{a}}$} \\
\hline \multicolumn{2}{|c|}{ Model } & \multicolumn{2}{|c|}{$\begin{array}{l}\text { Unstandardized } \\
\text { Coefficients }\end{array}$} & \multirow{2}{*}{$\begin{array}{l}\text { Standardized } \\
\text { Coefficients } \\
\text { Beta }\end{array}$} & \multirow[t]{2}{*}{$\mathbf{T}$} & \multirow[t]{2}{*}{ Sig. } \\
\hline & & B & Std. Error & & & \\
\hline & (Constant) & -0.590 & .487 & & .490 & .726 \\
\hline & Information Systems & .117 & .125 & .111 & 1.361 & .059 \\
\hline \multirow[t]{3}{*}{1} & Supplier Relationship & .217 & .123 & .211 & 1.433 & .069 \\
\hline & Order Processing & .338 & 137 & .436 & 2.177 & .004 \\
\hline & Inventory Management & .177 & .169 & .163 & 1.531 & .615 \\
\hline
\end{tabular}

a. Dependent Variable: Supply Chain Management

The regression model generated from the above regression results took the following form;

$\mathrm{Y}=0.117 \mathrm{X}_{1}+0.217 \mathrm{X}_{2}+0.338 \mathrm{X}_{3}+0.177 \mathrm{X}_{4}$

This section reported the relationship between the dependent variable (Supply Chain Management) and the independent variables (Information Systems, Supplier Relationship, Order Processing and Inventory Management). Table 1.3 above presents the coefficients of the estimated variables with their expected signs. It can therefore be construed from the table above that all the four predictors had a significant positive effect on the supply chain management at Kenya Seed Company Limited. From the analysis above, Order Processing was the variable with the highest significant effect at $33.8 \%$ followed by Inventory Management at $17.7 \%$, Supplier relationship at $21.7 \%$ while the variable "information Systems" had the least significant effect at $11.7 \%$ compared to the other variables. This module is therefore expected to be able to measure the variables comprehensively. This is in line with the findings of Nyongesa and Osoro (2019).

The predictor variable, information system, predicted $11.7 \%$ of Supply Chain Management, which clearly explains that variable factors like decision making on what to store and transport, communication, order tracking and tracing, forecasting, inventory monitoring and cost reduction were highly correlated with Supply Chain Management. Meaning, Ceteris paribus, a unit change in information system results in a 0.117 change in supply chain management. The relationship between supplier relationship and supply chain management had strength of $21.7 \%$ with a positive coefficient of 0.217 ; similarly the set of standardized beta coefficients suggest that adjusting for the effect of other explanatory variables, supplier relationship had a positive effect on supply chain management.

With an order processing system being the communication network that provides information necessary for management of interfaces between logistics and other functional areas of the firm as well as within logistics, this variable truly returned the highest effect on supply chain management from the respondents, where it recorded the strongest $33.8 \%$ effect on the dependent variable. This reflected that a unit change in the variable order processing resulted in a 0.338 change in Supply chain management at Kenya Seed Company Limited. Inventory Management on the other hand predicted $17.7 \%$ of supply chain management, thereby demonstrating a correlation with supply chain management at Kenya Seed Company Limited. This implied that a unit change in Inventory Management resulted in a 0.177 change in Supply chain management at Kenya Seed Company Limited. This echoes the findings of Mutava . (2014).

\section{3.1 CONCLUSION}

The research analysis results shows that the four keywords; information systems, supplier relationship, order processing and inventory management had a strong effect on the supply chain management at Kenya Seed Company Limited, This is justified by 
the correlation and regression results above. In general, the variable of information system needs to be given more attention since even by virtue of it being central to the operations of the company, it seems not to be rated as required by the respondents who are employees of Kenya Seed Company Limited. From the analysis, the variable of supplier relationship received a positive feedback and therefore the study concluded that the company has performed well in that regard although more effort is required. Order processing was the variable with the highest effect on supply chain management, however, the neutral responses constantly falling over $10 \%$ was a course to worry. The conclusion was either the areas mentioned have more than what meets the eye or the employees are not well enlightened about the systems in the company. The company seems to be doing well as regards inventory management although continuous improvement on it is needed in order to minimize the percentages appearing under the neutral columns.

\section{REFERENCES}

[1] Achuora, J., Arasa, R., \& Ochiri, G. (2014). Precursors to effectiveness of public procurement audits for Constituency Development Funds (CDF) in Kenya. European Scientific Journal, 8(25): 198-214.

[2] Agaba, E., \& Shipman, N. (2014). Public Procurement Reform in Developing Countries: The Ugandan Experience. USA: Pr Academics Press.

[3] Ali, A., Namusonge, G. \& Sakwa, M. (2016). Effect of Firm Managerial Risk Aversion on Corporate Hedging of Listed Firms in Nairobi Securities Exchange in Kenya. IJRDO Journal of Business Management, 2(7), 45-64.

[4] Amit, R., \&Schoemaker, P. J. H. (2013).Strategic assets and organizational rent.Strategic Management Journal, 14, 33-46.

[5] Andrew, A. (2016). Strategic sourcing process model. Journal of Business \& Industrial and Labor Relations Review, Volume 17: Pages 99-120.

[6] Araz, C., \& Ozkarahan, I. (2017). Supplier evaluation and management system for strategic sourcing based on a new multicriteria sorting procedure. International journal of production economics, 106(2),585606.

[7] Armstrong, M. (2016). Handbook on Personnel Management and Practice (6th ed.). London: Korgan Page Limited

[8] Arthur, P. (2016). An Overview of EC Policy on Procurement: Current Position and Future Prospects, Procurement Law Review, Vol. 1 No.1, pp.28-39.

[9] Aseka, J. (2014). Supplier selection criteria and performance of manufacturing firms listed in the Nairobi Stock Exchange. Nairobi, Kenya: Unpublished MBA project, University of Nairobi.

[10] Bai, C., \& Sarkis, J. (2013).Supplier Selection and Sustainability: a Grey rough Set evaluation. Working paper No. 2013 -05.

[11] Bailey, P., Farmer, D., Jessop, D., \& Jones, D. (2016). Purchasing Principles and Management (8th ed.). Great Britain: Prentice Hall. Financial Times.

[12] Bailey, S. (2016). Public Sector Economics: Theory and Practice. London: Macmillan.

[13] Bali O., Kose, E.,\&Gumus, S. (2013). Green supplier selection based on IFS and GRA Grey systems. Theory and Application 3(2):58-176.

[14] Bansal, H. S., Irving, P. G., \& Taylor, S. F. (2014).A three-component model of customer commitment to service providers.Journal of the Academy of Marketing Science, 32(3), 234-250.

[15] Barsemoi, H., Mwangagi, P., \& Asienyo, B.O. (2014). Factors Influencing Procurement Performance in Private Sector in Kenya. International Journal of Innovation and Applied Studies, 9(2):632-641.

[16] Barth, M. E., Beaver, W. H. and Landsman, W. R.(2013). `Relative Valuation Roles of Equity BookValue and Net Income as a Function of Financial Health', Journal of Accounting and Economics,(25): 134.

[17] Bartik L (2016). Supply chain management practices in institutions. Procurement Journal. Vol. 28
[18] Basheka and Tumutegyereize (2016). 'Access to health care in a system transition: the case of Bulgaria'. International Journal of Health Planning and Management 17:377-95.

[19] Basheka, B. (2016). Procurement Planning and Local Governance in Uganda: A Factor Analysis Approach. Uganda Management Institute.

[20] Beatty, R. P. and Ritter, J. R. (2016). 'Investment banking, reputation, and underpricing of initial

[21] Benton WC (2014), "Power influences in the supply chain", Journal of Business Logistics, Vol. 21 No.1, pp.49-73.

[22] Bergman, M. A., \& Lundberg, S. (2013). Tender evaluation and supplier selection methods in public procurement. Journal of Purchasing and Supply Management, 19(2), 73-83.

[23] Chalotra, V. (2013). Inventory Management and Small Firms Growth: An Analytical Study in Supply Chain. Vision, 17, 3(20-23): 213-222.

[24] Creswell, J. (2013). Research design: qualitative, quantitative, and mixed methods approaches. (4th Ed), Thousand Oaks: Sage Publications.

[25] Davis, F., \& Cobb, A. (2010). Resource Dependence Theory: Past and future, Research in the Sociology of Organizations, 28(1), 21-42.

[26] Evans, M. M. (2015), Impact of supply chain integration strategies on performance of pork processing industry in Rwanda (case of German butchery in Kigali). European Centre for Research Training and Development UK (www.eajournals.org).

[27] Farahani, (2011) Logistics Operations and Management: Concepts and Models (1st ed.), London: Elsevier Inc.

[28] Fatiha N. (2014). Customer service in supply chain management. A case study, Journal of Enterprise Information Management, 27(6) 786 - 801.

[29] Fugate, Brian S., John, T., M., \& Stank T. P. (2010). Logistics Performance:

[30] Efficiency, Effectiveness and Differentiation. Journal of Business Logistics, 31(1) 43-62

[31] Fugate, M, \& Stank T., P. (2010). Logistics Performance: Efficiency, Effectiveness and Differentiation: Journal of Business Logistics 31(1) 43-6.

[32] Ganesh Kumar, C. and Nambirajan, T. (2013), Supply Chain Management Components, Competitiveness and Organisational Performance: Causal Study of Manufacturing Firms. Asia-Pacific Journal of Management Research and Innovation, 9(4) 399-412.

[33] Gikonyo, N. (2016). Performance Monitoring and Quality Outcomes in Contracted Services. International Journal of Quality and Reliability Management, 19 (4), $396-413$.

[34] Kogoh, Z. B. K. (2015). Effect of outsourcing on performance of logistics industry in Kenya (Doctoral dissertation, Strathmore University).

[35] Kyusya, J. M. (2015). Effect of logistics outsourcing on the operational performance of shipping industry in Kenya (Doctoral dissertation, University of Nairobi.

[36] Kamande, M., W. (2011). The Impact of Clean Production on the Performance of Kenya Manufacturing Firms, Ph.D. (Economics) Dissertation .University of Dar es Salaam: Tanzania.

[37] Kilasi, L. B., Juma, D., \& Mathooko, P., M. (2013). The impact of Outsourcing of Logistics on the Competitive Advantage strategy of East African Breweries Limited: International Journal of Social Sciences and Entrepreneurship 1 (3), 521-52.

[38] Kothari, C. (2011). Research Methodology: Methods and techniques, 2nd edition.

[39] Lacity, \& Willcocks, L. P. (2015). Business process outsourcing studies: a critical review and research directions. In Formulating Research Methods for Information Systems (pp. 169-251). Palgrave Macmillan UK.

[40] Langley, J. (2015, Feb 15). 2016 Third party logistics study. The state of Logistics Outsourcing. New Delhi: New Age Tecno press.

[41] Lysons K., \& Farrington, B. (2012). Purchasing and Supply Chain Management. 8th Edition. Pearson Education Limited.

[42] Makabira, D.K., \& Waiganjo, E. (2014). Role of Procurement Practices on the Performance of Corporate Organizations in Kenya: A Case Study of Kenya National Police Service. International Journal of Academic Research in Business and Social Sciences,4(10): 369-384.

[43] Margetta, J. (2008). The power of virtual integration. Journal of supply chain Management. Vol.35, No.9. pp. 149-152.

[44] Marie Butler-Knight. ElSafty, S. (2015). Critical success factors of Six Sigma implementation in automotive industry in Egypt. SAE echnical Paper 201601-1270. 
[45] Masiko, D. M. (2013). Strategic procurement practices and procurement performance among commercial banks in Kenya. Nairobi, Kenya: Unpublished MBA project, University of Nairobi.

[46] Mathenge (2012). An Evaluation of the Impact of the Public Procurement Regulations on Procurement in Kenyan Public Universities.” MBA Project. Egerton University, Nakuru

[47] Mathieu, J. E., Tannenbaum, S. I., \& Salas, E. (2014). Influences of individual and situational characteristics on measures of training effectiveness. Academy of management journal, 35(4), 828-847.

[48] Magutu, Chirchir, \& Mulama, (2012). Challenges facing the Implementation of Outsourcing strategy at the Kenyatta National Hospital,Unpublished MBA Project, University of Nairobi.

[49] Mangarulkar, A., \& Dabade, U. (2012). New Tool Planning and Introduction System for Manufacturing of Engine Compo.

[50] Mutava, C. (2014). Impact of Public Procurement Procedures on Maintenance Works Case of the Ministry of Housing, National Social Security Fund and Kenyatta National Hospital. 1st ed. Kuala Lumpur: FIG.

[51] Mwangangi P., W. (2016). Influence of Logistics management on Manufacturing Firms in Kenya, phd thesis. Jomo Kenyatta University of Agriculture and Technology.

[52] Mwikali, R., \& Kavale, S. (2013). Factors Affecting the Selection of Optimal Suppliers in Procurement management. International Journal of Humanities and Social Science, 2 (14).54

[53] Nagati, H., \& Rebolledo, C. (2013). Supplier development efforts: The suppliers' point of view. Industrial Marketing Management, 42(2), 180-188.

[54] Nasra, B. H. (2014). Procurement performance and operational efficiency in telecommunication industry in Kenya. Nairobi, Kenya: Unpublished MBA project, University of Nairobi.

[55] Nasong'o, J, N. \& Osoro, A. (2019). Factors Affecting Savings And Internal lending Communities in Informal Finance Groups On Pastoral Communities In Kenya, A Case Of West Pokot County. International Journal of Scientific and Research Publications, Volume 9, Issue 5, May 2019721 ISSN 22503153

[56] Nelson, D., Moody, P. \& Stegner, J. (2014).The incredible payback. New York City,NY:AMACOM.

[57] Newman, R. A. (2016). Adaptive plasticity in development of Scaphiopus couchii tadpoles in desert ponds. Evolution, 774-783.

[58] Ng'ang'a, H. W. (2014). Supplier selection criteria and supply chain performance in non-governmental organizations in Kenya. Nairobi, Kenya: Unpublished MBA project, University of Nairobi.
[59] Njambi, E. \& Katuse, P. (2013). Third party logistics in distribution efficiency delivery for competitive advantage in fast moving consumer goods companies in Kenya, International Journal of Social Sciences and Entrepreneurship 1 (8), 15-27.

[60] Nyongesa, M, N. \& Osoro, A. (2019). Factors Affecting the Implementation of Procurement Policies and Procedures in Public Entities in Kenya, A Case of Trans-Nzoia County. International Journal of Scientific and Research Publications, Volume 9, Issue 5, May 201969 ISSN 2250-3153.

[61] Prathap, G., \& Mittal, R. (2010). A performance index approach to library collection: Performance Measurement and Metrics 11 (2), 259-65.

[62] Public Procurement Oversight Authority, (2012). PPOA Journal: October Edition, PPOA:Nairobi

[63] Pan, S., Ballot, E., Fontane, F., \&Hakimi, D. (2012). Environmental and economic issues arising from the pooling of SMEs' supply chains: case study of the food industry in Western France. Flexible Services and Manufacturing Journal, 1-27.

[64] Sultana, A. (2012). Impact of Training and Employee Performance. Interdisciplinary Journal of Contemporary Research in Business, 4(6), 646696.

[65] Somuyiwa \& Adewoye, (2010).Managing Logistics Information System: Theoretical Underpinning, Asian Journal of Business Management 2 (2), 41 47.

[66] Tukamuhabwa, Eyaa, S. \& Derek, F., (2011).Mediating Variables in the

[67] Relationship between Market Orientation and Supply Chain Performance: A Theoretical Approach; International Journal of Business and Social Science $2(22)$

[68] Wardaya, (2013).Improving Competitiveness of the National Industry of Logistics Service Providers through Collaboration from the Perspective of Consumer Goods Manufacturing Companies in East Jav: International Journal of Business and Management Invention 2 (5), 27-38.

[69] Wambui M. (2010). Analysis of Outsourcing at Kenya Armed Forces, Unpublished MBA Project: University of Nairobi.

[70] Wekesa, M. M., (2016). Determinants of Effective Fraud Management; A case study of Tier one Commercial Banks in Trans-Nzoia County. http://www.ijsrp.org, ISSN 2250-3153 (online), 6(10), 2016.

\section{AUTHORS}

First Author - Student: Joyclare Khakasa Wabuge:

Second Author - Lecturer: Dr. Anthony Osoro (PhD) JKUAT, Kenya 